\title{
Financial Development and Growth: evidence from Serbia
}

\author{
Article history: \\ Received: 24 January 2019 \\ Sent for revision: 4 February 2019 \\ Received in revised form: 18 March 2019 \\ Accepted: 19 March 2019 \\ Available online: 1 April 2019
}

\begin{abstract}
This paper studies the relationship between financial development and economic growth in Serbia. We focus on the influence of stock market and banking-sector development on growth. Using the framework of a neoclassical growth model, we investigate the impact of stock market liquidity and credit activity of banks on per-capita GDP growth rate. In lines with many previous results in the literature, we find a positive and statistically significant impact of stock market liquidity and bank credit on economic growth. We control for the usual determinants of growth, such as government consumption, foreign direct investments and inflation.
\end{abstract}

Keywords: economic growth, stock market, banks, transition economies

\section{Finansijska razvijenost i privredni rast: rezultati za Srbiju}

Apstrakt: Rad se bavi odnosom između finansijske razvijenosti i privrednog rasta u Srbiji. Istraživanje je usredsređeno na uticaj razvoja tržišta hartija od vrednosti i bankarskog sektora na rast. Koristeći okvir neoklasičnog modela rasta, istražujemo uticaj likvidnosti berze i kreditne aktivnosti banaka na stopu rasta bruto domaćeg proizvoda po glavi stanovnika. U skladu sa mnogim prethodnim rezultatima $u$ literaturi, nalazimo pozitivan $i$ statistički značajan uticaj likvidnosti berze $i$ kreditne aktivnosti banaka na ekonomski rast. $U$

\footnotetext{
${ }^{1}$ University of Belgrade, Faculty of Economics, milosbozovic@ekof.bg.ac.rs 
regresijama smo koristili kontrole za uobičajene determinante rasta, kao što su državna potrošnja, strane direktne investicije i stopa inflacije.

Ključne reči: ekonomski rast, berza, banke, privrede u tranziciji

\section{Introduction}

Economic growth is often associated with the quality of financial system. Intuitively, a developed financial market and a stable network of financial intermediaries foster more efficient resource allocation and flow of information. Many theoretical models provide predictions that confirm this simple intuition. These models mostly rely on endogenous growth and different roles played by financial system. Levine (2005) presents a detailed review of theoretical and empirical research related do the link between development of capital markets and macroeconomic performance. Empirical evidence shows that a positive influence of financial development on growth typically follows from a decrease in cost of capital in emerging and transition economies, or from an increase in total factor productivity in developed economies (See, for example, Papaioannou, 2007).

However, establishing causal relationship from financial development to economic growth empirically has been the crucial issue so far. King and Levine (1993) used a regression across different countries in one of the first attempts to test the existence of such a causality. They found that the size of the country's banking system relative to its Gross Domestic Product (GDP) predicts long-term growth rates, even when one controls for other explanatory variables. Other measures of financial depth have been used as well. For instance, Levine and Zervos (1998) show a similar causal link between stock market capitalisation and growth. Using instrumental variable approach and introducing controls for other determinants of growth did not change the original results qualitatively (see, for instance, Levine et al., 2000; or Beck and Levine, 2004).

Various mechanisms through which financial markets impact economic growth have also been studied. Again, Levine (2005) summarizes the main channels. These predominantly include informational efficiency, better corporate controls and monitoring of projects, efficient allocation of capital, pooling of savings, risk management and diversification, or more efficient exchange of goods and services (Claessens and Laeven, 2003; Demirgüç- 
Kunt et al., 2006; Beck, 2012). The availability of external finance is positively related to entrepreneurship, innovation and market entry (Klapper et al., 2006; Aghion et al., 2007; Ayyagari et al., 2011). It also facilitates growth and investment opportunities of existing companies (Rajan and Zingales, 1998; Beck et al., 2005, 2006). Small and medium-sized enterprises seem to exhibit a stronger impact of financial depth on firm performance and growth than the large ones (Beck et al., 2005, 2008a, 2008b).

On the flip side, the mechanism that makes finance beneficial to growth also leads to fragility and systemic risk. Although it is one of the core positive roles that financial industry has on the rest of the economy, the maturity and liquidity transformation comes with a side effect, as the system becomes susceptible to shocks, and prone to bank runs and liquidity shortages. The information asymmetries between lenders and borrowers alleviated by the banks is another potential source of fragility due to the agency conflicts between savers and banks. Carletti (2008) provides an overview of different sources of financial fragility. For instance, agency problems also promote increased risk-taking behaviour of banks. The negative externalities of bank failures have made the financial sector among the most regulated ones. They caused the establishment of various safety nets that act as (explicit or implicit) subsidies. This, in turn, incentivises aggressive risk-taking behaviour by the banks, as well as the associated high leverage (Demirgüç-Kunt and Kane, 2002).

More recent empirical findings indicate that the conventional finance-growth nexus changed after 1990s, differing across regions, countries, and income levels (Nili and Rastad 2007; Barajas et al., 2013), or firm size (Rioja and Valev, 2004a, 2004b). There might be even some evidence for the disappearance of the link, mostly as a results of more prevalent banking crises than in the earlier data (Rousseau and Wachtel 2011). Some papers also report the so-called "too much finance" effect, when financial development increases growth, but only to the extent beyond which additional deepening reduces it (Arcand et al., 2012; Beck et al., 2012; Aizenman et al., 2015). Possible explanations of this phenomenon may be sought in the negative impact on allocative efficiency and on crowding out of human capital away from more productive sectors of the economy during rapid expansions of financial sector (Cecchetti and Kharroubi, 2015; Dabla-Norris et al., 2015). Rajan (2005) highlights potential "catastrophic meltdowns" in large and complicated financial systems. Gennaioli et al. (2012) show that financial 
fragility and systemic risk can be increased by financial innovation even in the absence of leverage if tail risks are neglected.

Evidence from emerging markets shows many benefits in terms of growth and stability that follow from financial development. However, these benefits wane as financial markets and institutions become more developed: they mostly affect the total factor productivity growth, and somewhat less the capital accumulation. The speed of financial development and the extent of regulation are also important for the trade-off between stability and growth in emerging economies. See Sahay et al. (2015) for a detailed study of the relationship between financial development and growth in emerging markets.

In this paper, we study the relationship between quantifiable metrics of financial development and economic growth in Serbia. By combining quarterly and monthly data, we investigate the impact of stock market development and credit activity of banks on per-capita GDP growth rate. We control for the usual determinants of growth, such as government expenditure, foreign direct investments and inflation. We find a significant positive influence of stock market liquidity and credit activity of the banking sector on economic growth. To the best of our knowledge, this is the first study of the finance-growth nexus conducted on Serbian data.

The remainder of this paper is organized as follows. In Section 2, we describe the methodology used in this research. Section 3 describes the data and the variables. Section 4 presents and analyses the regression results. Section 5 concludes.

\section{Methodology}

Growth accounting is a useful tool for identification of determinants of economic growth of a country (Barro and Sala-i-Martin, 2004). These factors may include natural resources, geography, institutional quality, government policies and many others. In the context of this paper, we will focus on the role of financial institutions. We start from the neoclassical aggregate production function in period $t$ : 


$$
Y_{t}=A_{t} K_{t}^{\alpha}\left(L_{t} h_{t}\right)^{\beta}
$$

where $Y_{t}$ is the output, $A_{t}$ is the (Hicks-neutral) level of technology, $K_{t}$ is the capital stock, $L_{t}$ is the labour force, $h_{t}$ is the average human capital of workers, while $\alpha$ and $\beta$ measure the share of capital and quality-adjusted labour force in the economy, respectively. Under the assumption of nonincreasing returns to scale, $\alpha+\beta \leq 1$. Dividing both sides of equation (1) by $L_{t}$, we obtain the production function in the intensive form:

$$
y_{t}=A_{t} k_{t}^{\alpha} h_{t}^{\beta}
$$

where $k_{t}$ is the capital per worker. By taking logs of equation (2) and differentiating over time, we get:

$$
\frac{\dot{y_{t}}}{y_{t}}=\alpha \frac{\dot{\dot{k}_{t}}}{k_{t}}+\beta \frac{\dot{h_{t}}}{h_{t}}+\frac{\dot{A_{t}}}{A_{t}}
$$

where dots indicate time derivatives. Equation (3) relates per-capita output growth to the rate of change of physical capital (usually associated with investments), the rate of change of human capital (usually associated with education) and total factor productivity (i.e. the measure of efficiency of capital and labour utilisation in the production). The last term measures technical change as a Solow residual and includes all factors other than physical- and human-capital investment. The first two terms are typically endogenous, which makes equation (3) a useful analytical device for decomposition of growth factors, rather than a "deeper" structural equation that relates growth to its fundamentals.

Most empirical analyses of the effects of financial development on growth apply a variant of the following cross-country dynamic panel regression:

$$
\Delta \ln y_{i, t}=a+b \ln y_{i, t-1}+c^{\prime} X_{i, t}+\eta_{i}+\varepsilon_{i, t},
$$

where $y$ is the logarithm of real per-capita GDP, $X$ is the set of explanatory factors, $\eta$ accounts for unobserved country-specific effects and $\varepsilon$ is the error term. The subscript $i$ in equation (4) represents a country, while time-specific 
effects can be captured through time dummies. (See, for example, Beck and Levine, 2004, and the references cited therein.) The lag of log per-capita GDP, $\ln y_{i, t-1}$, accounts for the usual convergence term in neoclassical models (Barro and Sala-i-Martin, 2004). Most empirical studies find a significant and negative coefficient associated with this convergence term, if one controls for other growth factors $X$. This indicates that if a country is further away from the steady state it will have a higher GDP growth rate. The set of growth factors $X$ typically includes a proxy for accumulation of human capital (e.g. changes in years of schooling or student enrolment rates) and other controls that may affect productivity, including a proxy measure of financial development.

In this paper, we analyse the impact of financial development on growth by running a simpler version of the regression given by equation (4), applied on a single country. More specifically, we estimate a time-series regression of the form:

$$
\Delta \ln y_{t}=a+b \ln y_{t-1}+c^{\prime} X_{t}+\varepsilon_{t} .
$$

We use the following set of controls appropriate for a single-country regression:

- government expenditure (relative to GDP);

- foreign direct investments (relative to GDP);

- inflation rate;

- a measure of stock market development;

- a measure of banking sector development.

To capture the stock market development, we follow Beck and Levine (2004) and use turnover ratio as a measure of market liquidity, calculated as the value of traded shares divided by the market value of listed shares. To capture the banking sector development, we follow Rousseau and Wachtel (2000) and use M3 divided by GDP. Intuitively, the expansion of M3 monetary aggregate should serve as a proxy for credit activity of the banking sector. An alternative indicator, calculated as the value of commercial bank claims on the private sector divided by GDP, suggested by Levine and Zervos (1998) would certainly be a better one, as argued by Beck and Levine (2004). However, it was not possible to use such measure in this study due to relatively short time span of the available data on bank claims. For similar reasons, we also do not 
include a proxy for human capital accumulation, although it would be a reasonable control variable. Annual data on primary- and secondary-school enrollment rates are available from UNESCO Institute for Statistics database. For Serbia, they cover the period between 1999 and 2017. Annual data on government expenditures on education as a fraction of GDP (suggested by Barro and Sala-i-Martin, 2004 as a proxy for educational quality) are available from the same source, for the period between 2007 and 2016, with a gap in 2013.

\section{Data}

Our data consist of the real per-capita GDP growth rate as the dependent variable, and the following explanatory variables:

- lagged GDP per capita;

- government consumption as a fraction of GDP;

- foreign direct investments (FDI) as a fraction of GDP;

- inflation rate;

- turnover ratio;

- relative broad money (M3) as a fraction of GDP.

The dataset is organised in monthly time series and covers the period between January 2002 and January 2019. Quarterly data on GDP were obtained from the statistical database of the National Bank of Serbia (www.nbs.rs). They are available in constant and current prices in Serbian Dinars (RSD). Data on Serbian population for each year between 2002 and 2018 were taken from the World Bank (data.worldbank.org). Quarterly series of per-capita GDP was then constructed for each quarter by dividing GDP level by the number of inhabitants in the respective year. Monthly data on real GDP per capita were obtained by interpolating the quarterly levels with the growth rate of index of industrial production, available from the database of Statistical Office of the Republic of Serbia with a monthly frequency. Inflation rate was calculated from the consumer price index (CPI), by combining databases of the Statistical Office of the Republic of Serbia and the National Bank of Serbia. Government consumption as a fraction of GDP is available from the World Bank database (we use the same value for each month in a quarter). Data on net FDI in Euros are available from three separate reports of the National Bank of Serbia. They are then recalculated in RSD using the data 
on exchange rates available from the same source. Data on market capitalisation and turnover are available from the Belgrade Stock Exchange. For the sake of consistency, we use only data related to stocks, excluding other securities traded on the Exchange. Monetary aggregates are available with monthly frequency from the database of the National Bank of Serbia. Summary statistics for the key explanatory variables - the indicators of financial development - are shown in Table 1.

Table 1. Summary statistics for the indicators of financial development (monthly data)

\begin{tabular}{llc}
\hline \hline Statistic & Turnover ratio & M3/GDP \\
\hline Number of observations & 205 & 205 \\
Mean & 0.0220 & 0.3116 \\
Standard deviation & 0.0495 & 0.1722 \\
Min & 0.0005 & 0.0405 \\
Median & 0.0045 & 0.3406 \\
Max & 0.1980 & 0.6863 \\
\hline
\end{tabular}

Sources: National Bank of Serbia; The World Bank; Statistical Office of the Republic of Serbia; Belgrade Stock Exchange.

\section{Results and Discussion}

The regression results are summarised in Table 2. We use an ordinary leastsquares estimator with robust standard errors and monthly seasonal dummies. Seasonality is driven by the industrial production index, which is used for interpolation of quarterly GDP data. Four factors turn out to be highly significant: lagged GDP per capita, government consumption to GDP, growth rate of turnover ratio and logarithm of M3 to GDP. Together with nine out of eleven seasonal dummies, they explain around 85 percent of the variations in GDP growth rate. The F-statistic is also above the critical value for this regression (3.37 at 0.05 significance level).

The sign of the coefficient corresponding to initial GDP per capita is negative, which is in lines with basic economic intuition related to convergence. Foreign direct investments do not influence growth significantly. This in accord with the results of Beck and Levine (2004) obtained on a panel of 40 countries. However, in contrast to Beck and Levine (2004), we find that government consumption has a significant but negative impact on economic growth. The influence of government expenditure on growth is, in general, unclear, as the 
empirical evidence is inconclusive. Our result is consistent with Butkiewicz and Yanikkaya (2011) although Alexiou (2009) provides the opposite evidence for South-Eastern Europe. An interesting view on this controversy, including the emphasis on the role of interaction of government consumption and some other explanatory variables, is given by d'Agostino et al. (2016). Inflation rate is not significant at 0.05 level, again in lines with Beck and Levine (2004). The point estimate has the expected negative sign, indicating a dampening effect of inflation on GDP growth.

Table 2. Regression results (seasonal dummies excluded)

\begin{tabular}{|c|c|}
\hline Regressors & Coefficient \\
\hline Constant & $\begin{array}{l}4.6656 \\
(0.8551)\end{array}$ \\
\hline Lagged GDP per capita $^{\dagger}$ & $\begin{array}{l}-0.3221^{\pi \times x} \\
(0.0578)\end{array}$ \\
\hline Government consumption/GDP & $\begin{array}{l}-0.0094^{\pi \times \pi} \\
(0.0031)\end{array}$ \\
\hline FDI/GDP & $\begin{array}{l}-0.0491 \\
(0.1542)\end{array}$ \\
\hline Inflation rate $(\mathrm{CPI})$ & $\begin{array}{c}-0.0014 \\
(0.0007)\end{array}$ \\
\hline Turnover ratio (log diff.) & $\begin{array}{l}0.0194^{\pi \times \pi} \\
(0.0057)\end{array}$ \\
\hline $\mathrm{M} 3 / \mathrm{GDP}^{\dagger}$ & $\begin{array}{l}0.0414 \times \\
(0.0104)\end{array}$ \\
\hline$R^{2}$ & 0.8545 \\
\hline F-statistic & $56.36^{\star \star *}$ \\
\hline
\end{tabular}

Source: Author's own estimations.

Despite the underdevelopment of the stock market, its liquidity is positively correlated with the economic growth. The expansion of the stock exchange in Serbia was predominantly associated with the transition process, since the shares of government-owned enterprises were sold (directly or indirectly) through the exchange. The sharpest increase in the stock market 
capitalisation occurred between 2001 and 2008, after the Property Transformation Law of 2001 was implemented. The largest trading volumes were achieved between 2006 and 2008. This period coincides with one of the largest expansions of the Serbian economy in recent history, with an average growth rate of $6.2 \%$ per year. Global Financial Crisis brought a drastic fall in the turnover ratio during 2008 and in the first quarter of 2009.

The ratio of M3 to GDP, used as a proxy for credit activity of the banking sector, is significant and positive. Thus, the credit activity of banks seems to have had a major impact on growth. Both empirical and anecdotal evidence suggests that bank credit continues to be the major source of financing in Serbia, at least for large companies (see, for example, OECD 2017). The credit expansion has certainly more direct impact on GDP than the capital raised through the stock exchange. Nevertheless, the existence of a functional, deep and liquid financial market results in many positive externalities for the entire economy and the country's legal system. Our findings corroborate this intuition.

\section{Conclusion}

In this paper we study the relationship between financial development and economic growth in Serbia. Using a linear regression based on a neoclassical endogenous growth model, we find empirical evidence that the overall financial development is positively associated with economic growth. We reject the hypothesis that the indicators of stock market development and banking activity are unrelated to growth. Convergence factor, measured through the lagged GDP per capita, is also highly significant. We control for the usual growth determinants, such as government consumption, foreign direct investments and inflation.

The results are consistent with theories that emphasise an important positive role of financial markets and institutions on economic growth. They are also very much in lines with the findings summarised by Beck and Levine (2004), Levine (2005), Beck (2012), Sahay et al. (2015) and many other authors. Future research on this topic in Serbia would certainly benefit from an extended dataset, which would span longer periods of time or include additional measures of financial development, particularly on the bankingsector side. Additionally, a more exhaustive study could include other 
countries that are similar (e.g. transition or post-transition economies, SouthEastern Europe, etc.) Our results imply that creation of an economic and legal environment in which financial markets and institutions can fully develop should be high on the policy agenda.

\section{References}

Aghion, P., Fally, T. and Scarpetta, S. (2007), "Credit Constraints as a Barrier to the Entry and Post Entry Growth of Firms", Economic Policy Vol. 22, 731-779.

Aizenman, J., Jinjarak, Y. and Park, D. (2015), "Financial Development and Output Growth in Developing Asia and Latin America: A Comparative Sectoral Analysis", NBER Working Paper No. 20917, National Bureau of Economic Research, Cambridge, Massachusetts.

Alexiou, C. (2009), "Government Spending and Economic Growth: Econometric Evidence from the South Eastern Europe", Journal of Economic and Social Research, Vol. 11 (1), Pp 1-16.

Arcand, J. L., Berkes, E. and Panizza, U. (2012), "Too Much Finance?" IMF Working Paper 12/161, International Monetary Fund, Washington, DC.

Ayyagari, M., Demirgüç-Kunt, A. and Maksimovic, V. (2011), "Firm Innovation in Emerging Markets: The Role of Finance, Governance, and Competition", Journal of Financial and Quantitative Analysis, Vol. 46, Pp 1545-1580.

Barajas, A., Chami, R. and Yousefi, S.R. (2013), "The Finance and Growth Nexus Reexamined: Do All Countries Benefit Equally?", IMF Working Paper 13/130, International Monetary Fund, Washington, DC.

Barro, R. J. and Sala-i-Martin, X. (2004), Economic Growth, $2^{\text {nd }}$ ed., MIT Press, Cambridge, MA.

Beck, T. (2012), "The Role of Finance in Economic Development - Benefits, Risks, and Politics", in: Dennis Müller (ed.), Oxford Handbook of Capitalism, Oxford University Press, 2012.

Beck, T. and Levine, R. (2004), "Stock Markets, Banks, and Growth: Panel Evidence", Journal of Banking and Finance, Vol. 28, Pp 423-442.

Beck, T., Degryse, H. and Kneer, C. (2012), "Is more finance better? Disentangling intermediation and size effects of financial systems”, working paper, Tilburg University.

Beck, T., Demirgüç-Kunt, A. and Maksimovic, V. (2005), "Financial and Legal Constraints to Firm Growth: Does Size Matter?" Journal of Finance, Vol. 60, Pp 137-177.

Beck, T., Demirgüç-Kunt, A. and Maksimovic, V. (2008a), "Financing Patterns around the World: Are Small Firms Different?" Journal of Financial Economics, Vol. 89, Pp 467-487. 
Beck, T., Demirgüç-Kunt, A., Laeven, L. and Levine, R. (2008b), "Finance, Firm Size, and Growth", Journal of Money, Credit and Banking, Vol. 40, Pp 1379-1405.

Beck, T., Demirgüç-Kunt, A., Laeven, L. and Maksimovic, V. (2006), "The Determinants of Financing Obstacles", Journal of International Money and Finance, Vol. 25, Pp 932-952.

Butkiewicz, J.L. and Yanikkaya, H. (2011), "Institutions and the Impact of Government Spending on Growth", Journal of Applied Economics, Vol. 14 (2), Pp 319341.

Carletti, E. (2008), "Competition and Regulation in Banking", in: A.V. Thakor and A. Boot (eds.), Handbook of Financial Intermediation and Banking, Elsevier, Amsterdam, 2008.

Cecchetti, S.G. and Kharroubi, E. (2015), "Why Does Financial Sector Growth Crowd Out Real Economic Growth?”, BIS Working Paper 490, Bank for International Settlements, Basel.

Claessens, S. and Laeven, L. (2003), "Financial Development, Property Rights, and Growth", Journal of Finance, Vol. 58, Pp 2401-2436.

Dabla-Norris, E., Guo, S., Haksar, V., Kim, M., Kochhar, K., Wiseman, K. and Zdzienicka, A. (2015), "The New Normal: A Sector-Level Perspective on Growth and Productivity Trends in Advanced Economies", IMF Staff Discussion Note, International Monetary Fund, Washington, DC.

d'Agostino, G., Dunne, J.P. and Pieroni, L. (2016), "Government Spending, Corruption and Economic Growth", World Development, Vol. 84, Pp 190-205.

Demirgüç-Kunt, A. and Kane, E. (2002), "Deposit Insurance around the Globe? Where Does it Work?", Journal of Economic Perspectives, Vol. 16, Pp 175-195.

Demirgüç-Kunt, A., Love, I. and Maksimovic, V. (2006), "Business Environment and the Incorporation Decision", Journal of Banking and Finance, Vol. 30, Pp 2967-2993.

Gennaioli, N., Shleifer, A. and Vishny, R. (2012), "Neglected Risks, Financial Innovation, and Financial Fragility", Journal of Financial Economics, Vol. 104, Pp 452-468.

King, R.G. and Levine, R. (1993), "Finance and Growth: Schumpeter Might Be Right", Quarterly Journal of Economics Vol. 108, Pp 717-738.

Levine, R. (2005), "Finance and Growth: Theory and Evidence", in: P. Aghion and S.N. Durlauf (eds.), Handbook of Economic Growth, Elsevier, Amsterdam, Pp 865-934.

Levine, R. and Zervos, S. (1998), "Stock Markets, Banks, and Economic Growth", American Economic Review, Vol. 88, Pp 537-558.

Levine, R., Loayza, N. and Beck, T. (2000), "Finance and the Sources of Growth", Journal of Financial Economics, Vol. 58, Pp 261-300.

Nili, M. and Rastad, M. (2007), "Addressing the Growth Failure of the Oil Economies: The Role of Financial Development", Quarterly Journal of Economics and Finance, Vol. 46, Pp 726-740. 
Božović M.: Financial Development and Growth: evidence from Serbia

OECD (2017), Financing SMEs and Entrepreneurs 2017: An OECD Scoreboard, OECD Publishing, Paris.

Papaioannou, E. (2007), "Finance and Growth: A Macroeconomic Assessment of the Evidence from a European Angle", ECB Working Paper No. 787.

Rajan, R. (2005), "Has Financial Development Made the World Riskier?" NBER Working Paper 11728, National Bureau of Economic Research, Cambridge, Massachusetts.

Rajan, R.G. and Zingales, L. (1998), "Financial Dependence and Growth”, American Economic Review, Vol. 88, Pp 559-586.

Rioja, F. and Valev, N. (2004a), "Finance and the Sources of Growth at Various Stages of Economic Development", Economic Inquiry, Vol. 42, Pp 127-140.

Rioja, F. and Valev, N. (2004b), "Does One Size Fit All? A Re-examination of the Finance and Growth Relationship", Journal of Development Economics, Vol. 74, Pp 429-447.

Rousseau, P. and Wachtel, P. (2000), "Equity markets and growth: Cross-country evidence on timing and outcomes, 1980-1995", Journal of Banking and Finance, Vol. 24, Pp 1933-1957.

Rousseau, P. and Wachtel, P. (2011), "What is Happening to the Impact of Financial Deepening on Economic Growth?", Economic Inquiry, Vol. 49, Pp 276-288.

Sahay, R., Čihák, M., N'Diaye, P., Barajas, A., Bi, R., Ayala, D., Gao, Y., Kyobe, A., Nguyen, L., Saborowski, C., Svirydzenka, K., and Yousefi, S.R. (2015),

"Rethinking Financial Deepening: Stability and Growth in Emerging Markets", IMF Staff Discussion Note 15/08, International Monetary Fund, Washington, D.C. 